\title{
Visitors' willingness to pay for snow leopard Panthera uncia conservation in the Annapurna Conservation Area, Nepal
}

\author{
Maurice G. Schutgens, Jonathan H. Hanson, Nabin Baral and Som B. Ale
}

\begin{abstract}
The Vulnerable snow leopard Panthera uncia experiences persecution across its habitat in Central Asia, particularly from herders because of livestock losses. Given the popularity of snow leopards worldwide, transferring some of the value attributed by the international community to these predators may secure funds and support for their conservation. We administered contingent valuation surveys to 406 international visitors to the Annapurna Conservation Area, Nepal, between May and June 2014, to determine their willingness to pay a fee to support the implementation of a Snow Leopard Conservation Action Plan. Of the $49 \%$ of visitors who stated they would pay a snow leopard conservation fee in addition to the existing entry fee, the mean amount that they were willing to pay was USD 59 per trip. The logit regression model showed that the bid amount, the level of support for implementing the Action Plan, and the number of days spent in the Conservation Area were significant predictors of visitors' willingness to pay. The main reasons stated by visitors for their willingness to pay were a desire to protect the environment and an affordable fee. A major reason for visitors' unwillingness to pay was that the proposed conservation fee was too expensive for them. This study represents the first application of economic valuation to snow leopards, and is relevant to the conservation of threatened species in the Annapurna Conservation Area and elsewhere.
\end{abstract}

Keywords Carnivore conservation, contingent valuation, economic valuation, existence value, Panthera uncia, snow leopard, threatened species, wildlife policy

Supplementary material for this article is available at https://doi.org/10.1017/So030605317001636

\footnotetext{
Maurice G. Schutgens (Corresponding author) Space for Giants, Nanyuki PO Box 174, 10400, Kenya. E-mail mauriceschutgens@gmail.com

Jonathan H. Hanson* Department of Geography, University of Cambridge, Cambridge, UK

NABIN BARAL University of Washington, School of Environmental and Forest Sciences, Seattle, WA, USA

SOM B. Ale University of Illinois at Chicago, Biological Sciences, Chicago, IL, USA

${ }^{\star}$ Also at: Jubilee Farm CBS, Larne, UK

Received 28 May 2017. Revision requested 26 July 2017.

Accepted 24 October 2017. First published online 20 March 2018.
}

\section{Introduction}

The conservation of large carnivores is difficult and costly 1 (Linnell et al., 2001; Nelson, 2009; Dickman et al., 2011), and many have experienced significant global declines in range and population size (Ripple et al., 2014). With an estimated global population of 3,920-6,390 individuals (McCarthy \& Chapron, 2003; Snow Leopard Working Secretariat, 2013) spread across a range of over 1.2 million $\mathrm{km}^{2}$ in 12 countries of south and central Asia (Jackson et al., 2010), snow leopards Panthera uncia have recently been recategorized as Vulnerable on the IUCN Red List (McCarthy et al., 2017), suggesting that they are facing a high risk of extinction in the wild in the medium-term future. Nepal is home to c. 300-500 snow leopards, most of which inhabit the country's western regions, including the Annapurna Conservation Area (Jackson \& Ahlborn, 1990; Ale et al., 2016; DNPWC, 2017).

Threats to snow leopards in Nepal include prey reduction because of illegal hunting, retribution for livestock depredation, climate change, habitat degradation, wildlife crime and, more recently, Cordyceps fungus collection in alpine habitats. The fungi are believed to have aphrodisiac properties and can present a considerable source of income, but their intensive and unregulated harvesting contributes to the degradation of the fragile ecosystem (Jackson et al., 2010; DNPWC, 2017). All of these potential threats are present to varying degrees in Nepal's high altitude protected areas. Conflicts with local communities over livestock losses to snow leopards may be the most serious threat in the Annapurna Conservation Area (Wegge et al., 2004; Ale et al., 2014), a situation often aggravated by relative poverty (Jackson et al., 2010). A major component of Nepal's strategy to conserve the snow leopard and other mega-fauna has been the establishment and management of protected areas, an approach implemented globally to conserve biodiversity and maintain ecosystem integrity (Chape et al., 2005; Gaston et al., 2008). Although often considered effective for biodiversity conservation and poverty alleviation at the broad scale (Bruner et al., 2001; Balmford et al., 2002; Geldmann et al., 2013), the current protected areas approach may not adequately protect many threatened species at the small scale (Brooks et al., 2004; Mora \& Sale, 2011), especially where funding is inadequate (Bruner et al., 2004) and species have large range sizes (Jackson et al, 2010).

Jackson et al. (2010) identified increased funding as one potential solution for effective snow leopard conservation and conflict management in Nepal, and tourism has been 
proposed as a way to raise funds (DNPWC, 2017). Global tourism, valued at over USD 1.5 trillion in 2015 , is one of the fastest growing industries in the world (World Tourism Organization, 2016) and nature-based tourism is an important component (Gössling, 200o; Tisdell \& Wilson, 2012). Although the tourism industry is subject to external pressures such as political instability, infectious diseases, natural disasters and the uncertainties of the global economy, nature-based tourism is increasingly in demand (Emerton et al., 2006). Over a 10-year period, nature-based tourism, measured in the number of visitors to protected areas, increased at a rate of $4 \%$ per annum in developing countries (Balmford et al., 2009). This demand presents an opportunity for protected areas to charge fees that reflect the true value associated with their services as well as the threatened species within them (Laarman \& Gregersen, 1996; Walpole et al., 2001). To do so effectively for the Annapurna Conservation Area, a study eliciting the value of snow leopards to visitors is warranted.

Snow leopards, like other threatened species, can elicit both use and non-use values within the total economic value framework. Use values are derived from consumptive use of a resource, such as wildlife viewing or trophy hunting (Loomis \& White, 1996). For instance, in Hemis National Park in India, photographic safaris based on snow leopards have been developed to generate necessary funds for their conservation (Namgail et al., 2016). Non-use values, on the other hand, are derived from appreciating that snow leopards exist even if they will never be utilized, the existence value, and the value placed on knowing that snow leopards will be available for future generations, the so-called bequest value (Loomis \& White, 1996). Both use and non-use values can be elicited through empirical research and used for the preservation of snow leopards (Loomis \& White, 1996; Richardson \& Loomis, 2009). Although it might be difficult to value wildlife species accurately, an assessment of the total economic value of the snow leopard has the potential to influence conservation policies.

In this paper, we assess international visitors' willingness to pay a fee for snow leopard conservation in the Annapurna Conservation Area. We examine an array of visitors' characteristics affecting their willingness to pay in Annapurna, which is visited by over 100,000 international trekkers annually (Baral \& Dhungana, 2014). We outline the overall importance of this approach for the conservation of threatened species, particularly in the context of developing countries, and discuss policy implementations to ease financial pressure on the Conservation Area.

\section{Study Area}

The rugged Himalayan landscape of the $7,629 \mathrm{~km}^{2}$ Annapurna Conservation Area in north-central Nepal, the largest protected area in the country, ranges over 1,000$8,091 \mathrm{~m}$ and includes the world's tenth highest peak, Annapurna I. It is also renowned for containing the world's deepest valley and a large diversity of flora and fauna, supporting 22 different types of forest, 1,140 plant species, and over 100 species of mammals and 500 species of birds (ACAP, 1997). The Conservation Area is managed by an autonomous non-governmental organization, the National Trust for Nature Conservation, in partnership with local communities, through their Conservation Area Management Committees. As per the 2011 census, the human population of 87,832 relies heavily on agro-pastoralism and tourism. Tourist entry fees constitute the main source of revenue for management. In 2013 over 100,000 international tourists visited the Conservation Area (Baral \& Dhungana, 2014), attracted primarily by the Himalayan landscape, as well as its ecological and cultural diversity (ACAP, 1997). The world-famous Annapurna Circuit trekking route that circumnavigates the Annapurna massif within the Conservation Area is one of the most popular trekking routes in the country.

The Annapurna Conservation Area has a population of at least 100 snow leopards (Ale et al., 2016). The most recent estimates have suggested the presence of at least three adult snow leopards in an area covering c. $75 \mathrm{~km}^{2}$ within the Conservation Area's Mustang District (Ale et al., 2014). A similar density was reported from Manang District's Phu Valley (Wegge et al., 2004). These estimates represent a relatively high snow leopard density compared to other range countries (Jackson et al., 2010; Ale et al., 2016). Significant numbers of blue sheep Pseudois nayaur in and around the Annapurna massif are likely to constitute the main source of food for this population of snow leopards (Ale et al., 2014).

\section{Methods}

\section{Sampling and data collection}

During March and May 2014 we administered a written questionnaire in Basic English to 406 foreign tourists. The Annapurna Circuit trekking route was followed in a clockwise direction from Lower Mustang in the west to Manang in the east. Traveling the circuit in this direction meant we encountered new tourists on a daily basis, as the majority of trekkers follow the circuit in an anti-clockwise direction. We used cluster sampling of 33 hotels within villages along the route to identify a random sample of visitors. We selected 16 hotels randomly by lottery each day and approached tourists staying in these hotels after obtaining permission from the owners. Surveys were carried out in the evenings, when tourists spent time relaxing or waiting for meals. We used 20 questionnaires printed on a four-page booklet of laminated 
A3 paper and added the relevant bid amounts in permanent marker before distribution to minimize the amount of paper used. We shuffled the surveys before distribution to ensure a random distribution of bids. Prospective respondents were given a short briefing on the research project and then verbal consent was taken if they showed interest in participating. We provided participants with markers to complete their responses, which took 22.6 minutes on average $(\mathrm{SD}=9.5 ;$ range $=12-55$ minutes; $\mathrm{n}=58)$, and remained nearby so that respondents were able to clarify any questions with us. After entering the data, and before wiping out the writing on the questionnaire sheet, we photographed all questionnaires and catalogued them for future reference. The questionnaires were cleaned and then re-used the following evening with the next set of random bids. Out of a total of 572 questionnaire completion requests, 406 were returned, giving a response rate of $71.0 \%$. Of the 47 who gave their reason for not participating in the exercise $57.4 \%$ stated they were not interested in taking part, $14.9 \%$ mentioned language difficulties, $10.6 \%$ were too tired, $6.4 \%$ did not have time, $4.3 \%$ felt they did not know much about snow leopards, $4.3 \%$ stated that there was no point in this type of research and $2.1 \%$ were not allowed to write at that time because of their religious practices.

\section{Contingent valuation}

The contingent valuation method relies on surveys to estimate the value of environmental goods and services that are not traded in the conventional market (Arrow et al., 1993; Carson, 2000). By creating a hypothetical marketplace, people are asked to report their willingness to pay to obtain or forgo a specified product or service, rather than inferring it from observed behaviours in the regular market (Venkatachalam, 2004). The contingent valuation method has been used frequently to assess the willingness to pay of various types of stakeholders and for the protection of threatened and charismatic species (Walpole et al., 2001; Bandara \& Tisdell, 2005; Baral et al., 2007a, b; Wilson \& Tisdell, 2007; Richardson \& Loomis, 2009). The method has, however, been used less frequently for large carnivores (Lindsey et al., 2005; Richardson et al., 2014).

As the goal was to estimate the amount that visitors would be willing to pay using a single bound dichotomous question, we measured the compensating variation for the improvement in conservation practice. Therefore, willingness to pay was operationalized as the amount that must be subtracted from people's income to keep their utility constant:

$$
\mathrm{V}_{1}\left(\mathrm{y}-\mathrm{A}, \mathrm{p}, \mathrm{q}_{1} ; \mathrm{X} ; \psi\right)=\mathrm{V}_{0}\left(\mathrm{y}, \mathrm{p}, \mathrm{q}_{0} ; \mathrm{X} ; \psi\right)
$$

where $V$ denotes the indirect utility function, $y$ is income, $A$ is the bid amount, $p$ is a vector of prices faced by the individuals, $q_{\mathrm{o}}$ and $q_{1}$ are the alternative levels of conservation practice ( $q_{1}$ being improved quality), $X$ is a vector of other characteristics, and $\psi$ is a preference parameter. To maximize utility, the individuals would make a trade-off between income and conservation practice given their other characteristics. Individuals respond to the stated bid such that:

$$
R= \begin{cases}\text { "Yes" } & \text { if WTP }>\text { Bid } \\ \text { "No" } & \text { if WTP } \leq \text { Bid }\end{cases}
$$

where $R$ denotes the response, WTP is willingness to pay and Bid is the stated conservation fee posed in the question asking about the visitors' willingness to pay.

Following the contingent valuation scenario (Supplementary Material 1), visitors were presented with a single bound referendum-type question asking if they would be willing to pay a specific amount (USD $A$ ) as a conservation fee in addition to entry fees. One bid amount per questionnaire was randomly allocated from 12 proposed conservation fees: USD 5, 10, 20, 30, 40, 50, 60, 70, 80, 90, 100 and 120. These bid amounts were selected based on a literature review of the contingent valuation of threatened species and protected areas (Walpole et al., 2001; Bandara \& Tisdell, 2005; Baral et al., 2008), supplemented by prior experience of conducting similar studies elsewhere. Two debriefing questions were also included. An open-ended follow-up question solicited the most important reason for visitors' response regarding their willingness to pay the specified amount. These qualitative responses were later coded and tallied.

There is some criticism of the contingent valuation method concerning the reliability of results, potential biases and uncertainty of hypothetical markets (Venkatachalam, 2004; Bartczak \& Meyerhoff, 2013). Respondents may choose to state a lower willingness to pay if they are concerned that their responses may affect pricing policy, especially if they are likely to revisit the Conservation Area: the 'unrevealed motivation' bias (Walpole et al., 2001). The reverse may also be true, with individuals wanting to demonstrate their dedication to conservation. The strength of the contingent valuation approach, however, is its ability to capture non-use values, describe the socio-demographic characteristics of the target stakeholders and present hypothetical markets to estimate the value of the species in question (Ressurreicao et al., 2011). Careful survey design is crucial to minimize hypothetical biases and our design reflected a real market scenario as closely as possible by choosing the entry fee as a payment vehicle. Similar to Baral et al. (2008), we also reported to respondents that the Annapurna Conservation Area might re-assess pricing policy based on the survey's results. 


\section{Data analysis}

We used logit regression to model the relationship between the dichotomous dependent variable (willingness to pay) and the independent variables. Ordinary least square regression violates the normality assumption when the response variable is binary, so the logit model is most appropriate in such a case. Based on a review of other contingent valuation studies conducted in relation to protected areas (Baral et al., 2008; Baral \& Dhungana, 2014) and threatened or charismatic species (Walpole et al., 2001; Bandara \& Tisdell, 2005; Baral et al., 2007a, b; Wilson \& Tisdell, 2007; Richardson et al., 2014), we hypothesized that respondents who were offered lower bid amounts, had greater knowledge of snow leopards, supported the implementation of the Snow Leopard Conservation Action Plan, were interested in participating in nature-based activities in the Conservation Area, travelled in a larger group (Baral et al., 2008), used a guide (Baral et al., 2008), spent longer in the Conservation Area, were more satisfied with their trip (Baral et al., 2008), were a member of an environmental organization, were older, had a higher income level, were more educated, and were male would all be more likely to pay a higher snow leopard conservation fee than others. With respect to the latter, the influence of being male is suggested by potential income disparity between men and women, as shown in other contingent valuation studies (Horton et al., 2003).

The following equation was estimated:

Probability $(\mathrm{WTP})=$

$a+b_{1}$ bid amount $+b_{2}$ snow leopard knowledge

$+b_{3}$ support for Snow Leopard Conservation Action Plan

$+b_{4}$ expectation to see snow leopards

$+b_{5}$ group size $+b_{6}$ use of a guide

$+b_{7}$ time in Annapurna Conservation Area

$+b_{8}$ trip satisfaction $+b_{9}$ environmental membership

$+b_{10}$ age $+b_{11}$ gender $+b_{12}$ active in labour force

$+b_{13}$ education level + error

where $a$ is the constant and $b_{\mathrm{i}}$ are the coefficients of the explanatory variables. The goodness-of-fit of the model was estimated using the maximum log-likelihood ratio. We tested the model for misspecification and examined various residual plots.

\section{Econometrics of willingness to pay}

We presented the willingness to pay question as a referendum in which the respondents were asked if they would or would not be willing to pay a given bid amount $A$. It was assumed that visitors would maximize their utility while expressing their willingness to pay the specified bid amount to implement the Action Plan. The probability that a respondent would be willing to pay a given bid amount was assumed to follow a standard logistic variate (Hanemann, 1984):

$$
\operatorname{Prob}(\text { Yes } \mid A, X)=\left(1+e^{-\left(\alpha+\beta A+X^{\prime} \Phi\right)}\right)^{-1}
$$

where $\alpha$ is a constant parameter, $\beta$ is the coefficient of the bid variable $A, X$ is the vector of other explanatory variables influencing the response, and $\Phi$ is the vector of the corresponding slope parameters. Using estimated parameters of equation (3), the median amount that visitors were willing to pay was computed as

$$
\mathrm{WTP}=\frac{\alpha+\bar{X}^{\prime} \Phi}{\beta}
$$

The mean amount was calculated by numerical integration of the expected values of willingness to pay, from USD 5.00 to the maximum bid amount of USD 120.00, using equation (3). We obtained the $95 \%$ confidence intervals for the mean amount visitors were willing to pay running the Monte Carlo simulation developed by Krinsky \& Robb (1986). The simulation was implemented in STATA (StataCorp, College Station, USA) with the wtpcikr command (Estimate Krinsky and Robb Confidence Intervals for Mean and Median Willingness to Pay; Jeanty, 2007).

\section{Results}

\section{Visitor characteristics}

Of the 396 respondents, $1.5 \%$ had no formal education, $20.9 \%$ had completed high school, $12.9 \%$ had an associate degree/diploma, 29.3\% had an undergraduate/bachelor's degree, $27.78 \%$ had a postgraduate/master's degree, and $7.6 \%$ had a doctoral degree. The mean age of respondents was 32 years $(n=388)$. A total of 393 respondents completed the employment question with $34.6 \%$ employed full-time, $31.6 \%$ temporarily employed, $15.0 \%$ students, $7.9 \%$ other, $6.1 \%$ employed part-time, $4.1 \%$ retired and $0.8 \%$ homemakers. Less than a fifth $(17.1 \%)$ of the respondents were members of environmental organizations $(n=393)$. About $88 \%$ of respondents answered the question about their total household income for the year 2013. They fell into the following income brackets: <USD 20,000 (32.0\%), USD 20-30,000 (13.4\%), USD 30-40,000 (10.0\%), USD 40-50,000 (8.4\%), USD 50-60,000 (7.8\%), 60-70,000 (6.1\%), 70-80,000 (5.9\%) and >USD 80,000 (16.4\%). Visitors from 41 countries were recorded in the sample $(\mathrm{n}=398)$; the most common were the USA (14.1\%), Israel (11.8\%), Germany (10.6\%), the UK (9.6\%) and Australia (7.3\%). The average trip satisfaction score for the 395 respondents was 8.5 on a 10-point scale. Almost all of those surveyed $(98.7 \%)$ said that they would recommend the 
Conservation Area to their family and friends $(n=396)$, and the majority $(66.3 \%, \mathrm{n}=338)$ stated that there was no substitute for the Annapurna Conservation Area in the world.

\section{Trip characteristics}

Of the 405 respondents, $69.1 \%$ reported that visiting the Annapurna Conservation Area was the primary purpose of their trip to Nepal. Most visitors (88.2\%) had never visited the Conservation Area before. Just under half (47.9\%) of the respondents were traveling with friends in a group. The average group size was $3.3(n=405)$. Approximately two-thirds (63.3\%) of those who participated in the survey had hired a trekking guide while in the Conservation Area $(\mathrm{n}=406)$, and of these, $35.2 \%$ rated their guide's knowledge as 'excellent', $45.5 \%$ rated it as 'good', $15.87 \%$ rated it as 'fair' and $3.5 \%$ described it as 'poor' $(\mathrm{n}=145)$. Visitors spent on average 15.89 days in the Conservation Area $(n=388$; $\mathrm{SD}=7.7$ ), and their mean daily expenditure was USD $26.16(\mathrm{n}=392 ; \mathrm{SD}=45.1) \quad($ Table 1$)$. Trekking/hiking was by far the most important activity attracting respondents $(n=390)$ to the Conservation Area (89.0\%). This was followed by nature photography $(2.8 \%)$, visiting cultural sites (2.6\%), other (2.3\%), research/study (1.0\%), mountaineering (1.0\%), wildlife viewing or bird watching (o.8\%), visiting ethnic museums (0.3\%), and more than one reason (0.3\%).

\section{Support for the Snow Leopard Conservation Action Plan}

When asked to rate the importance of the implementation of the Action Plan, 21.2\% stated this was extremely important, $54.3 \%$ very important, $20.7 \%$ somewhat important, $3.3 \%$ a little important and $0.5 \%$ not at all important. When asked about their motivations for supporting the implementation of the Action Plan, the most important motivation that respondents who had rated the implementation as very important or extremely important was: 'I believe that snow leopards have a right to exist' (93.3\%, $n=401)$; followed by 'I enjoy knowing snow leopards exist in Annapurna even if nobody ever sees one' $(80.7 \%, \mathrm{n}=400)$; 'I enjoy knowing future generations will get pleasure from snow leopards in Annapurna' (80.3\%, $\mathrm{n}=402$ ); 'I enjoy knowing other people get pleasure from snow leopards in Annapurna' $(74.6 \%, n=402)$; 'I may want to see snow leopards in the future in Annapurna' (64.9\%, $n=402)$.

\section{Willingness to pay a snow leopard conservation fee}

Four hundred of the 406 respondents answered the willingness to pay question (98.5\%). About half of the respondents (49.0\%) were willing to pay the bid amount stated in their surveys. The mean amount visitors were willing to pay was USD 59.05 (confidence interval 49.70-66.33) per trip
(Fig. 1). The logit regression model correctly classified $70.5 \%$ of cases $\left(X^{2}=100.02, P<0.01\right.$, Table 2$)$. Regarding the model's Pearson residual, deviance residual, Pregibon leverage and multicollinearity, no obvious problems were observed in the diagnostic plots. Of the 13 explanatory variables, three were statistically significant predictors of willingness to pay: number of days spent in the Conservation Area, support for the Action Plan and the bid amount. A negative association between the willingness to pay and the bid amount indicated that the higher the bid amounts the lower the probability of their acceptance. For each dollar increase in the proposed conservation fee, the probability of visitors' willingness to pay decreased by $3.0 \%$. The probability of willingness to pay would increase by $71.4 \%$ if respondents also supported the implementation of the Action Plan. Similarly, each additional visitor day in the Conservation Area increased the probability of a positive response to the willingness to pay question by $6.7 \%$.

When the proportion of visitors' willingness to pay was plotted against their snow leopard knowledge assessment scores, a clear linear trend was observed in bivariate analysis; however, this relationship faded away during multivariate analysis. Contrary to our expectation, the knowledge variable did not explain the significant variance in the willingness to pay.

\section{Reasons for and against willingness to pay for snow leopard conservation}

The majority of respondents (93.5\%) answered the followup question asking to give a reason for their response to the willingness to pay question. Respondents who were willing to pay gave reasons slightly more frequently (95.4\%) than those were not willing to pay (92.5\%). The top three reasons for positive responses were that the visitors liked the idea of protecting nature, considered the proposed fees to be reasonable, and felt that conservation of snow leopards is crucial. A major reason for visitors' unwillingness to pay was that the proposed fee was too expensive (Table 3 ).

\section{Projected impact of conservation fee}

To understand the possible financial impacts of imposing a snow leopard conservation fee on the local economy we first calculated the gross economic impact of tourism following the methodology of Baral et al. (2008) based on the estimated visitation rate for the Annapurna Conservation Area in 2014 (Table 4). We asked survey participants how many days they planned to be in the Conservation Area and how much they expected to spend each day. On average, visitors stayed in the Conservation Area for 15.89 days and spent USD 26.16 per day, meaning that during their trip to the Conservation Area visitors spend on average USD 
TABLE 1 Summary of variables used in the Logit Regression Model.

\begin{tabular}{|c|c|c|}
\hline Variables & Description & Mean \pm SD \\
\hline Bid amount & $\begin{array}{l}\text { Respondents were asked varying \& randomly drawn conservation fees between USD } 5 \text { and } 120 \\
\text { (ratio scale) }\end{array}$ & $59.05 \pm 35.22$ \\
\hline $\begin{array}{l}\text { Snow leopard } \\
\text { knowledge }\end{array}$ & $\begin{array}{l}\text { Respondents were asked a number of questions relating to snow leopards, with } 1 \text { for a correct } \\
\text { answer, otherwise } 0 \text { (nominal scale) }\end{array}$ & $3.79 \pm 1.72$ \\
\hline $\begin{array}{l}\text { Implementing Snow } \\
\text { Leopard Conservation } \\
\text { Action Plan }\end{array}$ & $\begin{array}{l}\text { Respondents were asked how important it was to implement the Action Plan, on a five-point } \\
\text { scale: not at all important }=1 \text {, a little important }=2 \text {, somewhat important }=3 \text {, very important- } \\
=4 \text {, extremely important }=5 \text { (ordinal scale) }\end{array}$ & $3.92 \pm 0.77$ \\
\hline $\begin{array}{l}\text { Expectation of seeing } \\
\text { snow leopards }\end{array}$ & $\begin{array}{l}\text { Respondents were asked whether the presence of snow leopards affected their decision to visit, } \\
\text { on a five-point scale: not at all important }=1 \text {, a little important }=2 \text {, somewhat important }=3 \text {, } \\
\text { very important }=4 \text {, extremely important }=5 \text { (ordinal scale) }\end{array}$ & $1.41 \pm 0.88$ \\
\hline Group size & $\begin{array}{l}\text { Respondents were asked the number of people, including the respondent, travelling to the } \\
\text { Conservation Area on a trip together (ratio scale) }\end{array}$ & $3.27 \pm 2.58$ \\
\hline Use of a guide & Respondents who hired a guide were coded 1 , otherwise 0 (binary scale) & $0.37 \pm 0.48$ \\
\hline $\begin{array}{l}\text { Visitor days in } \\
\text { Annapurna }\end{array}$ & $\begin{array}{l}\text { Respondents were asked the number of days they intended to stay in the Conservation Area } \\
\text { (ratio scale) }\end{array}$ & $15.89 \pm 7.67$ \\
\hline Trip satisfaction & $\begin{array}{l}\text { Respondents were asked to rate their overall experience on a scale of } 1-10,10 \text { being the most } \\
\text { positive (ordinal scale) }\end{array}$ & $8.47 \pm 1.07$ \\
\hline $\begin{array}{l}\text { Environmental } \\
\text { membership }\end{array}$ & $\begin{array}{l}\text { Respondents who reported to be members of environmental organizations were coded } 1 \text {, } \\
\text { otherwise } 0 \text { (binary scale) }\end{array}$ & $0.17 \pm 0.37$ \\
\hline Age & $\begin{array}{l}\text { Respondents were asked to state the year they were born, which was subtracted from } 2014 \text { to give } \\
\text { age (ratio scale) }\end{array}$ & $32.19 \pm 11.08$ \\
\hline Gender & $\begin{array}{l}\text { Respondents who identified themselves as men were coded } 1 \text { and women were coded } 0 \text { (binary } \\
\text { scale) }\end{array}$ & $0.58 \pm 0.49$ \\
\hline Active in labour force & $\begin{array}{l}\text { Respondents were considered active in labour force (1) if they were employed full-time or } \\
\text { part-time, otherwise not (0) (binary scale) }\end{array}$ & $0.41 \pm 0.49$ \\
\hline Education & $\begin{array}{l}\text { Respondents were asked to record highest level of education attained measured on a } 6 \text {-point } \\
\text { scale: no degree achieved }=1 \text {, secondary education }=2 \text {, associate degree/diploma }=3 \text {, bachelor's } \\
\text { degree }=4 \text {, master's degree }=5 \text {, doctorate degree }=6 \text { (ordinal scale) }\end{array}$ & $3.83 \pm 1.28$ \\
\hline
\end{tabular}

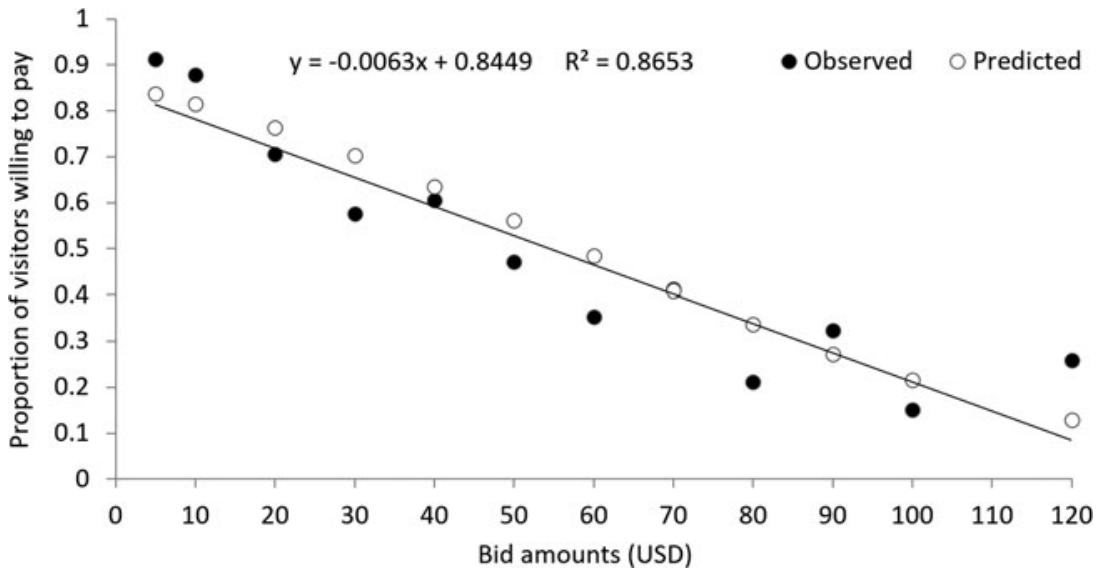

FIG. 1 A demand function derived from the observed positive responses to the willingness to pay question. The predictions based on the econometric model are shown in open circles. A linear trend line is fitted to the observed frequencies shown in filled circles.
415.68. We used this figure and corresponding visitation rates (adjusted for willingness to pay a snow leopard conservation fee) to calculate the gross economic impact on the local economy in each scenario. Park revenue was calculated by multiplying the number of expected visitors (adjusted for willingness to pay) by the entrance fee (USD 27.00). The expected snow leopard revenue was calculated by multiplying the number of expected visitors (adjusted for willingness to pay) by the snow leopard fee. In doing so, we were able to clearly gauge the impact of imposing a snow leopard fee on the local economy, one of the primary concerns that must be considered (Table 4 ).

\section{Discussion}

The results of this study indicate that foreign visitors are willing to pay USD 59.05 per trip on average, in addition to the USD 27.00 entrance fee, to support the implementation of the Snow Leopard Conservation Action Plan in the 
TABLE 2 Logit regression model of variables influencing responses to the willingness to pay question.

\begin{tabular}{lclrrr}
\hline Willingness to pay & Coefficient & Std. Error & $\mathrm{z}$ & $\mathrm{P}>\mathrm{Z}$ & Effect size (\%) \\
\hline Bid amount & -0.0308 & 0.0041 & -7.51 & 0.001 & -3.0 \\
Knowledge about snow leopards & 0.0047 & 0.0776 & 0.06 & 0.951 & 0.5 \\
Implementing Action Plan & 0.5386 & 0.1899 & 2.84 & 0.005 & 71.4 \\
Expectation of seeing snow leopards & 0.0261 & 0.1518 & 0.17 & 0.864 & 2.6 \\
Group size & 0.0741 & 0.0532 & 1.39 & 0.164 & 7.7 \\
Use of a guide & 0.4442 & 0.2983 & 1.49 & 0.136 & 55.9 \\
Visitor days in Conservation Area & 0.0652 & 0.0243 & 2.68 & 0.007 & 6.7 \\
Satisfaction from the trip & 0.0372 & 0.1200 & 0.31 & 0.757 & 3.8 \\
Environmental membership & 0.4623 & 0.3586 & 1.29 & 0.197 & 58.8 \\
Age & 0.0207 & 0.0137 & 1.51 & 0.131 & 2.1 \\
Gender & -0.0662 & 0.2635 & 0.25 & 0.802 & -6.4 \\
Active in labour force & 0.1803 & 0.2849 & 0.63 & 0.527 & 19.8 \\
Education & 0.0000 & 0.1137 & 0.00 & 1.000 & 0.0 \\
Constant & -2.9194 & 1.3976 & 2.09 & 0.037 & \\
\hline
\end{tabular}

Likelihood-ratio $\chi_{10}^{2}=100.02, \mathrm{P}<0.01, \mathrm{n}=346$, correctly classified cases $=70.52 \%$.

TABLE 3 Reasons for response to willingness to pay question.

\begin{tabular}{lc}
\hline Description & Frequency $(\%)$ \\
\hline Reasons why visitors were willing to pay an increased fee $(\mathbf{n}=\mathbf{1 8 8})$ & $23.9 \%$ \\
To protect nature, forests, wildlife, ecosystems, or environment & $21.3 \%$ \\
I can afford it; the entry fee is reasonable & $15.4 \%$ \\
Snow leopards must be protected/conserved & $9.6 \%$ \\
Tourists/visitors should pay to mitigate their negative impacts & $9.0 \%$ \\
I like to donate to worthy causes, general philanthropy & $9.0 \%$ \\
Conditional support, only if funds are judiciously used & $7.4 \%$ \\
The area is beautiful, unrivalled \& unique & $3.7 \%$ \\
Likelihood of success & $0.5 \%$ \\
To support economic development of the area & $67.2 \%$ \\
Reasons why visitors were unwilling to pay an increased fee (n= 186) & $9.1 \%$ \\
I cannot pay; the fee is too expensive & $4.3 \%$ \\
Concerns about corruption, misuse \& leakage of funds & $4.3 \%$ \\
There are other more important concerns e.g. clean drinking water & $3.8 \%$ \\
Tourists/visitors should not be the only ones to pay & $3.8 \%$ \\
It is the job of the Nepalese government & $2.2 \%$ \\
Snow leopards are not important & $1.6 \%$ \\
I already support other causes & $1.6 \%$ \\
Entry fee is too expensive for shorter visits & $1.6 \%$ \\
The project is unlikely to succeed & $0.5 \%$ \\
Conservation fees should go to all species & \\
I prefer to visit other places & \\
\hline
\end{tabular}

TABLE 4 Projected impact of introducing a snow leopard conservation fee in the Annapurna Conservation Area.

\begin{tabular}{llllrl}
\hline $\begin{array}{l}\text { Candidate snow } \\
\text { leopard fee (USD) }\end{array}$ & $\begin{array}{l}\text { \% willing } \\
\text { to pay }\end{array}$ & $\begin{array}{l}\text { Expected } \\
\text { visitors }\end{array}$ & $\begin{array}{l}\text { Expected park } \\
\text { revenue (USD) }\end{array}$ & $\begin{array}{l}\text { Expected snow } \\
\text { leopard revenue (USD) }\end{array}$ & $\begin{array}{l}\text { Gross economic } \\
\text { impact (USD) }\end{array}$ \\
\hline 0 & 100 & 129,966 & $3,509,082$ & 0 & $53,935,890$ \\
5 & 91 & 118,269 & $3,193,264$ & 591,345 & $49,162,082$ \\
10 & 88 & 114,370 & $3,087,992$ & $1,143,700$ & $47,541,354$ \\
20 & 71 & 92,276 & $2,491,448$ & $1,845,517$ & $38,357,229$ \\
60 & 35 & 45,488 & $1,228,179$ & $2,729,286$ & $18,908,493$ \\
\hline
\end{tabular}

Adapted from Baral et al. (2008), based on 129,966 visitors in 2014 (visitor numbers rounded to the nearest whole number). 
Annapurna Conservation Area. Their willingness to pay was influenced by the time participants spent in the Conservation Area, their support for the Action Plan and the bid amount. The main motivation to support the Snow Leopard Conservation Action Plan was that the snow leopard had the right to exist. Given these results, the critical question is thus how to translate this economic value attributed to snow leopards by international tourists into financial resources for conservation initiatives in the Conservation Area. A logical policy implication would be to introduce a conservation fee for foreign visitors to the Conservation Area that directly raises funds for snow leopard conservation initiatives without significantly reducing visitation rates.

The introduction of a snow leopard conservation fee set at the mean amount that visitors were willing to pay in this study could theoretically generate c. USD 3 million in funds per year. This is a significant proportion of the estimated USD 3.15 million required to implement the national Snow Leopard Conservation Action Plan for Nepal in 2017-2021 (DNPWC, 2017). However, there would be significant financial repercussions to the local economy (Table 4) as a result of decreased visitation rates to the Conservation Area. It is likely that such an aggressive pricing policy would be met with resistance from local tourism entrepreneurs whose livelihoods would be threatened (Laarman \& Gregersen, 1996; Walpole et al., 2001; Baral et al., 2008), and could result in increasing resentment towards snow leopards: a counterproductive outcome. Some international visitors may also perceive this proposed fee to be too high.

The implementation of a fee set at this study's mean amount that visitors are willing to pay, as well as that determined by similar studies elsewhere, may be problematic because of the uncertainties involved in translating a hypothetical scenario into reality. Although there are many possible consequences of introducing or increasing a fee, the economic impacts should be considered carefully. For example, both Walpole et al. (2001) and Baral et al. (2008), investigating visitor's willingness to pay entrance fees to protected areas, avoided recommending the implementation of the studies' mean amount that visitors were willing to pay in favour of a more 'reasonable' fee (based on expected additional revenue, impact on visitation rates and impact on local economies) to be introduced either incrementally or over a trial period. Given these inherent uncertainties, we recommend that the Conservation Area management reviews its current pricing policies and considers the implementation of a snow leopard conservation fee, albeit cautiously and in consultation with local communities and stakeholders.

Despite our best efforts to minimize potential biases within this contingent valuation study, some biases cannot be ruled out completely, so the results must be viewed cautiously. For many visitors the Conservation Area trek is a once-in-a-lifetime activity, as suggested by the fact that only $12 \%$ of participants had visited the area previously. It is possible that participants may have agreed to higher bid amounts as they were unlikely to return to the Conservation Area. Similarly, although responses were treated anonymously, participants may have agreed to higher bid amounts because of perceived peer-pressure to demonstrate their willingness to support this cause to fellow travellers or ourselves. The mean amount that visitors are willing to pay should thus be seen only as an indication of willingness to support the conservation of the snow leopard, a species with currently no use value in the Conservation Area, rather than a figure to be implemented without further consideration.

Respondents' open-ended responses explaining why they were willing to pay a snow leopard conservation fee also have potential management implications for the Annapurna Conservation Area. The most common reason cited for supporting a conservation fee was to enhance the overall protection of nature. The Conservation Area management may consider showcasing their conservation efforts more prominently to visitors, which could enhance visitor satisfaction during the trip and increase their willingness to pay (Tisdell et al., 2007; Baral et al., 2008). To secure long-term support for the initiative, clear disclosure on how funds would be spent will be necessary to build trust and achieve optimal acceptance of the scheme, as frequently mentioned in open-ended responses (Table 3 ).

This study contributes to research conducted on the total economic value framework, using the contingent valuation method, with specific reference to threatened species. The snow leopard has no apparent use value within the Conservation Area at the time of writing, and although this could change, this study illustrates the importance of understanding and quantifying existence value, as has been emphasized elsewhere (e.g. Han \& Lee, 2008). Nearly $90 \%$ of respondents were not influenced to any degree in their decision to visit the Conservation Area by the possibility of encountering a snow leopard, and yet our results indicate an opportunity to generate revenue for the conservation of this species.

\section{Conclusions}

International visitors are willing to pay for snow leopard conservation in the Annapurna Conservation Area and their decision is influenced by the number of days they spend in the Area and their views on snow leopard conservation. However, the mean amount they would be willing to pay (USD 59.05) would prove difficult to implement given the likely detrimental impacts on the local economy and visitation rates. Although we do not propose the introduction of a specific amount, a snow leopard conservation fee implemented in the Conservation Area would help offset the costs 
of snow leopard conservation in the area and possibly the entire country. This decision however, should be viewed in light of the likely economic, social and political impacts. Although there is significant potential to raise funds for snow leopard conservation in the Conservation Area, it may not be feasible in other places within snow leopard range where the tourism industry is not well established. The Annapurna Conservation Area has a reputation as a world-class trekking destination, but other protected areas in Nepal harbouring snow leopards attract fewer visitors. Therefore, the potential for generating tourism income to subsidize snow leopard conservation projects may be limited at other snow leopard sites within or outside Nepal. We propose further research across other range states to determine visitors' willingness to pay for snow leopard conservation elsewhere and stress the importance of investigating the economic value of a species as a tool for its conservation, especially in developing countries.

\section{Acknowledgements}

We thank the Annapurna Conservation Area staff for providing support and assistance, the hotel owners who gave us permission to conduct research on their premises, participants for their enthusiasm and patience, and N. Shrestha and J. Schuurmans for collecting the data during fieldwork. All necessary permits were obtained prior to fieldwork and the authors followed the guidelines developed by the British Sociological Association. JHH was supported by Economic and Social Research Council Grant ES/J500033/1.

\section{Author contributions}

MGS, JHH, NB and SBA conceptualized the study and methodology. NB analysed the data. JHH acquired funding. MGS and JHH conducted the field work and prepared the original draft. NB and SBA reviewed and edited the draft. All authors approved the final version for submission.

\section{References}

ACAP (1997) Management Plan for Annapurna Conservation Area. Annapurna Conservation Area Project, Pokhara, Nepal.

Ale, S.B., Shah, K.B. \& Jackson, R. (2016) South Asia: Nepal. In Snow Leopards: Biodiversity of the World: Conservation from Genes to Landscapes. 1st ed. (eds P.J. Nyhus, T. McCarthy \& D. Mallon), pp. 471-479. Elsevier, Amsterdam, Netherlands.

Ale, S.B., Shrestha, B. \& Jackson, R. (2014) On the status of snow leopard Panthera uncia in Annapurna, Nepal. Journal of Threatened Taxa, 6, 5534-5543.

Arrow, K., Solow, R., Portney, P.R., Leamer, E.E., Radner, R. \& Schuman, H. (1993) Report of the NOAA panel on contingent valuation. Federal Register, 58, 4601-4614.
Balmford, A., Beresford, J., Green, J., Naidoo, R., Walpole, M. \& MANiCA, A. (2009) A global perspective on trends in nature-based tourism. PLoS Biology 7(6): e10oo144.

Balmford, A., Bruner, A., Cooper, P., Costanza, R., Farber, S., Green, R.E. et al. (2002) Economic reasons for conserving wild nature. Science, 297, 950-953.

BANDARA, R. \& Tisdell, C. (2005) Changing abundance of elephants and willingness to pay for their conservation. Journal of Environmental Management, 76, 47-59.

Baral, N. \& Dhungana, A. (2014) Diversifying finance mechanisms for protected areas capitalizing on untapped revenues. Forest Policy and Economics, 41, 60-67.

Baral, N., Gautam, R., Timilsina, N. \& Bhat, M.G. (2007a) Conservation implications of contingent valuation of critically endangered White-rumped Vulture Gyps bengalensis in South Asia. The International Journal of Biodiversity Science and Management, $3,145-156$.

BARAL, N., Stern, M.J. \& Bhattarai, R. (2008) Contingent valuation of ecotourism in Annapurna Conservation Area, Nepal: implications for sustainable park finance and local development. Ecological Economics, 66, 218-227.

Baral, N., Stern, M.J. \& Heinen, J.T. (2007b) Integrated conservation and development project life cycles in the Annapurna Conservation Area, Nepal: Is development overpowering conservation? Biodiversity and Conservation, 16, 2903-2917.

BartcZak, A. \& Meyerhoff, J. (2013) Valuing the chances of survival of two distinct Eurasian lynx populations in Poland-do people want to keep the doors open? Journal of Environmental Management, 129, 73-80.

Brooks, T.M., Bakarr, M.I., Boucher, T., Da Fonseca, G.A.B., Hilton-Taylor, C., Hoekstra, J.M. et al. (2004) Coverage provided by the global protected area system: is it enough? BioScience, 54, 1081-1091.

Bruner, A.G., Gullison, R.E. \& Balmford, A. (2004) Financial costs and shortfalls of managing and expanding protected area systems in developing countries. BioScience, 54, 1119-1126.

Bruner, A.G., Gullison, R.E., Rice, R.E. \& Da Fonseca, G.A.B. (2001) Effectiveness of parks in protecting tropical biodiversity. Science, 291, 125-128.

CARson, R.T. (2000) Contingent valuation: a user's guide. Environmental Science \& Technology, 34, 1413-1418.

Chape, S., Harrison, J., Spalding, M. \& Lysenko, I. (2005) Measuring the extent and effectiveness of protected areas as an indicator for meeting global biodiversity targets. Philosophical Transactions of the Royal Society B, 360, 443-455.

Dickman, A.J., Macdonald, E.A. \& Macdonald, D.W. (2011) A review of financial instruments to pay for predator conservation and encourage human-carnivore coexistence. Proceedings of the National Academy of Sciences of the United States of America, 108, 13937-13944.

DNPWC (2017) Snow Leopard Conservation Action Plan (2017-2021). Department of National Parks and Wildlife Conservation, Kathmandu, Nepal.

Emerton, L., Bishop, J. \& Thomas, L. (2006) Sustainable Financing of Protected Areas: A Global Review of Challenges and Options. The World Conservation Union (IUCN), Gland, Switzerland.

Gaston, K.J., Jackson, S.F., Cantú-SAlazar, L. \& Cruz-Piñón, G. (2008) The ecological performance of protected areas. Annual Review of Ecology, Evolution and Systematics, 39, 93-113.

Geldmann, J., Barnes, M., Coad, L., Craigie, I.D., Hockings, M. \& BURGESS, N.D. (2013) Effectiveness of terrestrial protected areas in reducing habitat loss and population declines. Biological Conservation, 161, 230-238. 
Gössling, S. (2000) Sustainable tourism development in developing countries: some aspects of energy use. Journal of Sustainable Tourism, 8, 410-425.

HAN, S.Y. \& LEE, C.K. (2008) Estimating the value of preserving the Manchurian black bear using the contingent valuation method. Scandinavian Journal of Forest Research, 23, 458-465.

Hanemann, M.W. (1984) Welfare evaluations in contingent valuation experiments with discrete responses. American Journal of Agricultural Economics, 66, 332-341.

Horton, B., Colarullo, G., Bateman, I.J. \& Peres, C.A. (2003) Evaluating non-user willingness to pay for a large-scale conservation programme in Amazonia: a UK/Italian contingent valuation study. Environmental Conservation, 30, 139-146.

JACKSON, R. \& Ahlborn, G. (1990) The role of protected areas in Nepal in maintaining viable populations of snow leopards. In International Pedigree Book of Snow Leopards Panthera uncia Volume 6 (ed. L. Blomqvuist), pp. 51-69. Helsinki Zoo, Helsinki, Finland.

Jackson, R.M., Mishra, C., McCarthy, T. \& Ale, S.B. (2010) Snow leopards, conservation and conflict. In The Biology and Conservation of Wild Felids (eds D.W. Macdonald \& A.J. Loveridge), pp. 417-430. Oxford University Press, Oxford, UK.

Jeanty, P.W. (2007) Constructing Krinsky and Robb confidence intervals for mean and median willingness to pay (WTP) using stata. In 6 th North American Stata Users' Group Meeting, Boston, Massachusetts.

KRINSKY, I. \& Roв B, A.L. (1986) On approximating the statistical properties of elasticities. The Review of Economics and Statistics, 68, 715-719.

Laarman, J.G. \& Gregersen, H.M. (1996) Pricing policy in nature-based tourism. Tourism Management, 17, 247-254.

Lindsey, P.A., Alexander, R.R., Du Toit, J.T. \& Mills, M.G.L. (2005) The potential contribution of ecotourism to African wild dog Lycaon pictus conservation in South Africa. Biological Conservation, 123, 339-348.

Linnell, J.D.C., Swenson, J.E. \& Anderson, R. (2001) Predators and people: conservation of large carnivores is possible at high human densities if management policy is favourable. Animal Conservation, 4, 345-350.

Loomis, J.B. \& White, D.S. (1996) Economic benefits of rare and endangered species: summary and meta-analysis. Biological Economics, 18, 197-206.

McCarthy, T., Mallon, D., Jackson, R., Zahler, P. \& McCarthy, K. (2017) Panthera uncia. The IUCN Red List of Threatened Species 2017: e.T22732A50664030. Http://www. iucnredlist.org/details/22732/o [accessed 7th October 2017].

McCarthy, T.M. \& Chapron, G. (eds) (2003) Snow Leopard Survival Strategy. ISLT and SLN, Seattle, USA.

Mora, C. \& SAle, P.F. (2011) Ongoing global biodiversity loss and the need to move beyond protected areas: a review of the technical and practical shortcomings of protected areas on land and sea. Marine Ecology Progress Series, 434, 251-266.

Namgail, T., Majumder, B., Dadul, J., Agvaantseren, B., Allen, P., Dashzeveg, U. et al. (2016) Incentive and reward programs in snow leopard conservation. In Snow Leopards (eds T. McCarthy \& D. Mallon), pp. 163-178. Elsevier, London, UK and New York, USA.
Nelson, F. (2009) Developing payments for ecosystem services approaches to carnivore conservation. Human Dimensions of Wildlife, 14, 381-392.

Ressurreição, A., Gibbons, J., Dentinho, T.P., Kaiser, M., SAntos, R.S. \& EdWARDS-Jones, G. (2011) Economic valuation of species loss in the open sea. Ecological Economics, 70, 729-739.

Richardson, L. \& Loomis, J. (2009) The total economic value of threatened, endangered and rare species: an updated meta-analysis. Ecological Economics, 68, 1535-1548.

Richardson, L., Rosen, T., Gunther, K. \& Schwartz, C. (2014) The economics of roadside bear viewing. Journal of Environmental Management, 140, 102-110.

Ripple, W.J., Estes, J.A., Beschta, R.L., Wilmers, C.C., Ritchie, E. G., Hebblewhite, M. et al. (2014) Status and ecological effects of the world's largest carnivores. Science, https://doi.org/10.1126/ science.1241484.

Snow Leopard Working Secretariat (2013) Global Snow Leopard and Ecosystem Protection Program. Http://www.globalsnowleopard. org/ [accessed 15 February 2018].

Tisdell, C. \& Wilson, C. (2012) Nature-based Tourism and Conservation: New Economic Insights and Case Studies. Edward Elgar Publishing, Cheltenham, UK.

Tisdell, C., Swarna Nantha, H. \& Wilson, C. (2007) Endangerment and likeability of wildlife species: how important are they for payments proposed for conservation? Ecological Economics, 6o, 627-633.

Venkatachalam, L. (2004) The contingent valuation method: a review. Environmental Impact Assessment Review, 24, 89-124.

Walpole, M.J., Goodwin, H.J. \& Ward, K.G.R. (20o1) Pricing policy for tourism in protected areas: lessons from Komodo National Park, Indonesia. Conservation Biology, 15, 218-227.

Wegge, P., Pokheral, C.P. \& Jnawali, S.R. (2004) Effects of trapping effort and trap shyness on estimates of tiger abundance from camera trap studies. Animal Conservation, 7, 251-256.

Wilson, C. \& Tisdell, C. (2007) How knowledge affects payment to conserve an endangered bird. Contemporary Economic Policy, 25, 226-237.

World Tourism Organization (2016) UNWTO Annual Report 2015. UNWTO, Madrid, Spain.

\section{Biographical sketches}

Maurice Schutgens works as a project manager for an elephant conservation NGO in north central Kenya. He is particularly interested in the fields of human-wildlife conflict mitigation and the impacts of the illegal wildlife trade. JONATHAN HANSON is researching the human dimensions of snow leopard conservation. He is particularly interested in the intersections between livestock farming and wildlife conservation. NABIN BARAL is interested in the human dimensions of natural resource management, resilience of social-ecological systems, sustainable tourism and protected area management. He researches the intricate linkages between nature and society. SOM ALE is a wildlife ecologist. He works on snow leopard research, education and conservation. 